\title{
BIOMARKER CANDIDATES IDENTIFIED IN BEHCET'S DISEASE USING INTEGRATIVE ANALYSIS
}

\author{
Tuba SEVIMOĞLU \\ Uskudar University, Bioengineering Department, İstanbul, TURKEY \\ tuba.sevimoglu@uskudar.edu.tr
}

(Geliş/Received: 27.09.2020; Kabul/Accepted in Revised Form: 20.02.2021)

\begin{abstract}
Behcet's Disease is a rare auto inflammatory and autoimmune disorder that causes blood vessel inflammation throughout the body and can affect all organ systems. The pathophysiology of the disease is still under investigation. Since the symptoms are varying it is difficult to diagnose and there are no sufficient medical treatments for the disease. In this study Behcet's Disease gene (Samples from isolated CD4+ T cells and CD14+ monocytes) and miRNA expression (samples from platelet free plasma) datasets were statistically analyzed. Differentially expressed genes for CD4+ T cells and CD14+ monocytes have been identified and miRNA associated with this data were listed. Protein-protein and miRNA - target gene interaction networks were constructed and hubs of these networks were identified for both cell types. Metabolites and metabolic pathways associated with gene expression data were displayed and enrichment analysis was done to identify associated signaling pathways and diseases. Differentially expressed miRNAs of platelet free plasma samples were also identified. The analysis results indicated cell/tissue type dependent genomic reprogramming. Mutual hub miRNAs (hsa-miR-17-5p, hsa-miR-603, hsa-miR375, hsa-miR-107, hsa-miR-454-3p, hsa-miR-650, hsa-miR-142-3p and hsa-miR-765) in all cell/tissue types and metabolites (guanidinoacetate and histone-L-lysine) for CD4+ and CD14+ cells may be considered as biomarker candidates. Future studies focusing on these candidate biomarkers might yield a diagnostic kit or design of enhanced therapeutics for Behcet's Disease.
\end{abstract}

Key Words: Behcet's Disease, gene expression, miRNA, interaction networks, metabolites

\section{Bütünleştirici Analiz Kullanarak Behçet Hastalığında Biyobelirteç Adayları Belirlenmesi}

ÖZ: Behçet Hastalığı, vücutta kan damarı iltihabına neden olan ve tüm organ sistemlerini etkileyebilen nadir bir oto enflamatuar ve otoimmün hastalıktır. Hastalığın patofizyolojisi halen araştırılmaktadır. Semptomlar değişkenlik gösterdiği için teşhis edilmesi zordur ve hastalık için yeterli tıbbi tedavi yoktur. Bu çalışmada Behçet Hastalığı gen (izole edilmiş CD4 + T hücreleri ve CD14 + monositlerinden örnekler) ve miRNA ekspresyonu (trombosit içermeyen plazmadan örnekler) veri setleri istatistiksel olarak analiz edilmiştir. CD4 + T hücreleri ve CD14 + monositleri için farklı şekilde ifade edilen genler tanımlanmış ve bu verilerle ilişkili miRNA listelenmiştir. Protein-protein ve miRNA - hedef gen etkileşim ağları oluşturulmuş ve bu ağların merkezi olanları her iki hücre tipi için belirlenmiştir. Gen ekspresyon verileri ile ilişkili metabolitler ve metabolik yollar ortaya konulmuş ve ilişkili sinyal yollarını ve hastalıklarını tanımlamak için zenginleştirme analizi yapılmıştır. Trombosit içermeyen plazma örneklerinin farklı olarak ifade edilen miRNA'ları da tanımlanmıştır. Analiz sonuçları, hücre/doku tipine bağlı genomik yeniden programlamayı göstermiştir. Tüm hücre/doku türlerinde merkezi miRNAlar (hsa-miR-17-5p, hsa-miR-603, hsa-miR-375, hsa-miR-107, hsa-miR-454-3p, hsa-miR-650, hsa-miR-142-3p and hsa-miR-765) ve CD4 + ve CD14 + hücreleri için metabolitler (guanidinoasetat ve histon-L-lizin) biyobelirteç adayları 
olarak belirlenmiştir. Gelecekte yapılacak olan ve bu aday biyobelirteçlere odaklanan deneysel çalışmalar ile bir teşhis kiti veya geliştirilmiş terapötiklerin tasarımı gerçekleştirilebilir.

Anahtar Kelimeler: Behçet Hastalı̆̆ı, gen ifadesi, miRNA, etkileşim ağları, metabolitler

\section{INTRODUCTION}

Behcet's disease, which was first described by Hulusi Behçet in 1937, is a rare auto-inflammatory polygenetic disease that causes blood vessel inflammation and mostly presents itself as oral and genital ulcers and skin lesions. The disease pathogenesis has not been illuminated clearly (van der Houwen and van Laar 2020). Genetic and environmental factors take part in the immunopathogenesis of the disease (Tong et al. 2019). Symptoms of the disease are varying and are spread over time which makes it difficult to diagnose. And since it is a rare disease designing a diagnostic kit is also overlooked.

Gene expression studies, which started in 1977, mostly identify and evaluate mRNA levels of a particular gene. Presently the most broadly applied techniques for transcriptome analysis are qPCR and expression microarrays (Segundo-Val and Sanz-Lozano 2016). These techniques can also be used for miRNA expression analysis. miRNA's are short noncoding RNA's that take a crucial part in posttranscriptional regulation of gene expression. In a study done by Pucetti and coworkers gene expression and network analysis of BD was accomplished. Their results indicated highly connected clusters enriched in several signaling pathways such as T and B cell activation, type I IFN, JAK-STAT, and TLR (Puccetti et al. 2018a). In another study miRNA expression profiles of Behcet's Disease patients were analyzed. They determined miRNA markers associated with the disease which target pathways such as TNF and IFN gamma signaling pathways (Puccetti et al. 2018b).

Protein interactions mediate biological processes therefore it is important to interpret networks of these interactions in order to understand human diseases (Sevimoglu and Arga 2014). miRNA - Target gene interactions should also be evaluated to explore the genetic mechanism induced by miRNA expression. Both interaction networks should be assessed to get a holistic view of the mechanism. Hub molecules usually have greater connectivity than the other molecules in a network. Several well-known hub proteins take an influential part in diseases such as p53 and BRCA1 (Bertolazzi et al. 2013).

Metabolites are intermediates or end products of cellular metabolism and they can be used as biomarker in disease diagnostics. Exploring the metabolic pathways these metabolites are involved in may give us an idea of what is going on inside the metabolism in a disease state.

In the current study statistical analysis of gene expression and miRNA expression datasets for Behcet's Disease were done. Differentially expressed genes (DEGs) and miRNA were identified. Protein-protein and miRNA-target gene interaction networks were constructed and hubs of these interaction networks were put forward. Transcriptional regulators of the differentially expressed genes were established. Metabolites, metabolic pathways, signaling pathways and diseases associated with Behcet's Disease were also determined. Mutual as well as cell/tissue type specific disease mechanism was elucidated through this computational analysis.

\section{MATERIALS AND METHODS}

\subsection{Identification of Transcriptome and miRNAome}

Datasets associated with Behcet's Disease (GSE61399 and GSE145191) were obtained from Gene Expression Omnibus (GEO). The samples for GSE61399 dataset were isolated CD14+ monocytes and CD4+ $\mathrm{T}$ cells from PBMC. The sample type for GSE145191 was platelets-free plasma. DEGs for both cell types and miRNA for platelet free plasma samples were determined separately via GEO2R (Barrett et al. 2013), an online analysis tool. For False Discovery Rate Benjamini-Hochberg method was selected (Benjamini and Hochberg 1995; Smyth et al. 2011). p-value $<0.05$ and fold change (FC) were selected as cut off values. Genes with fold change values less than 0.65 were listed as downregulated and genes with fold change 
values more than 1.5 were listed as upregulated for both cell types. The same rule was applied for differential miRNA expression. The DEG - protein associations were established using bioDBnet, online database (Mudunuri et al. 2009). Transcription Factors of Behcet's Disease DEGs for both cell types were identified using HTRIDB (Human Transcriptional Regulation Interactions database) (Bovolenta et al. 2012).

\subsection{Construction of Interaction Networks}

A protein interaction network of Behcet's Disease proteins for both cell types from GSE61399 data was constructed using protein interaction data obtained from the BIOGRID (Release: 3.4.164) database (ChatrAryamontri et al. 2017). miRNA - target gene interactions for both datasets (GSE61399 and GSE145191) were also mapped using the miRTarbase repositories (Chou et al. 2018). The networks were constructed via online visualization tool Cytoscape (version 3.8.0). The hubs of the protein interaction as well as miRNA- target gene interaction networks were identified using Cytohubba plug in of Cytoscape (version 3.8.0) (Chin et al. 2014; Excoffier et al. 2017). Two mostly commonly used metrics, degree and betweenness centrality, were selected in the identification of hub proteins and hub miRNA. The degree metric counts the number of interactions a protein has, and betweenness centrality calculates how many times a protein is situated on the shortest path between two proteins in a network.

\subsection{Disease and Signaling Pathway Enrichment}

Enrichment analysis is a method used to identify functional profile of a group of genes to better understand the underlying biological processes surrounding this gene list. Differentially Expressed Behcet's Disease genes for both cell types were enriched to explore gene - disease and signaling pathway associations using DAVID (v6.8) (The Database for Annotation, Visualization and Integrated Discovery) an online bioinformatics tool (Huang et al. 2009), which uses information from Kyoto Encyclopedia of Genes and Genomes (Kanehisa et al. 2017) and The Genetic Association Database (GAD). Analysis results with a cut-off value of $\mathrm{p}<0.05$ were selected for statistical significance.

\subsection{Reporter Metabolite and Metabolic Pathway Analysis}

BIOMET Toolbox was used to integrate DEGs of each cell type (for GSE61399 dataset) into Human Metabolic Model HMR 2.0 (Agren et al. 2013; Mardinoglu et al. 2014). Benjamini correction was used and metabolites with $\mathrm{p}<0.05$ were accepted as statistically significant. MBRole bioinformatics tool (LópezIbáñez et al. 2016) was used to identify metabolic pathways as well as diseases associated with these metabolites.

\section{RESULTS}

In this study, gene (GSE61399) and miRNA (GSE145191) expression datasets of Behcet's disease were analyzed and up/down regulated genes and miRNA were uncovered. For GSE61399 dataset there are two different cell types. Analysis for these cell types were done separately. For CD4+ T cells there are 127 upregulated and 342 downregulated DEGs. Seven of the DEGs for CD4+ T cells are TFs (KLF4, LEF1, PLAGL1, STAT1, STAT2, ZBTB44 and ZEB2). Four of the TFs are upregulated and three of them are downregulated. For CD14+ monocytes samples, there are 473 upregulated and 568 downregulated DEGs. 28 of the DEGs for this data are also TFs (AHR, ARNT, BCL11A, E2F4, E4F1, ELF1, ELK1, FLI1, FOXO3, IKZF1, JUND, LRRFIP1, NFAT5, NFATC3, NR1D1, NR2C2, PAX8, POU2F1, RARA, RBPJ, SPDEF, TCF3, THRA, VDR, ZEB2, ZNF417, ZNF419 and ZXDC). 11 of the TFs are upregulated and 17 of them are downregulated. The number of downregulated DEGs for both cell types are higher than the upregulated ones. There are 73 mutual DEGs between both data. While 19 of the mutual DEGs were upregulated in both cell types, 26 of the mutual DEGs were downregulated. 29 mutual DEGs changed expression 
direction according to their cell type. Only one mutual DEGs is a TF (ZEB2) and it is downregulated in CD4+ and upregulated in CD14+ cells.

The PPI network for both cell types were also constructed. The PPI network for CD4+ T cells has 200 nodes and 199 edges, and the PPI network for CD14+ monocytes has 814 nodes and 3055 edges (Figure 1).

A

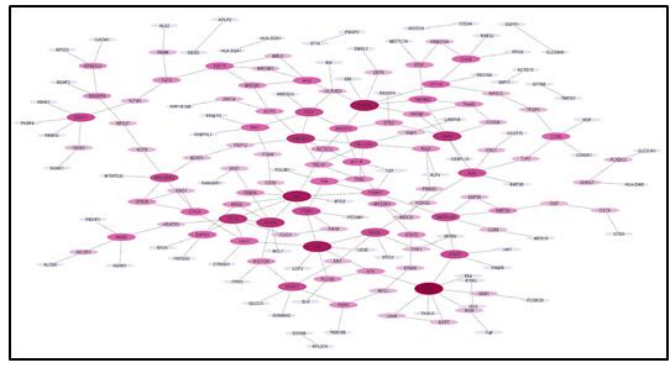

C

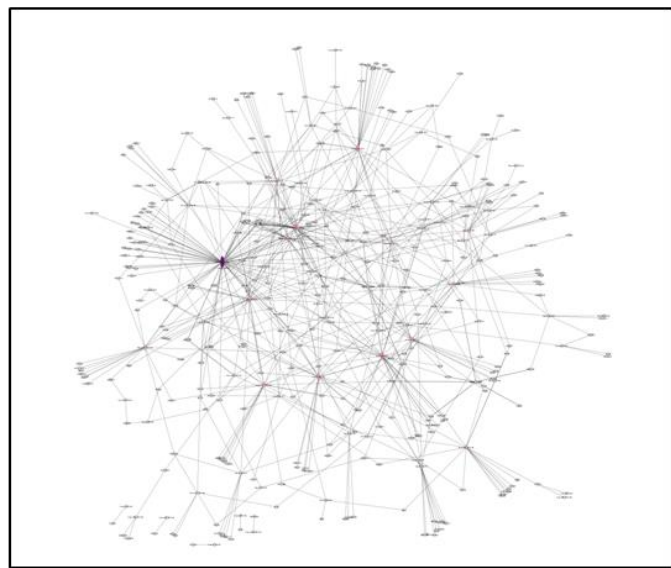

B

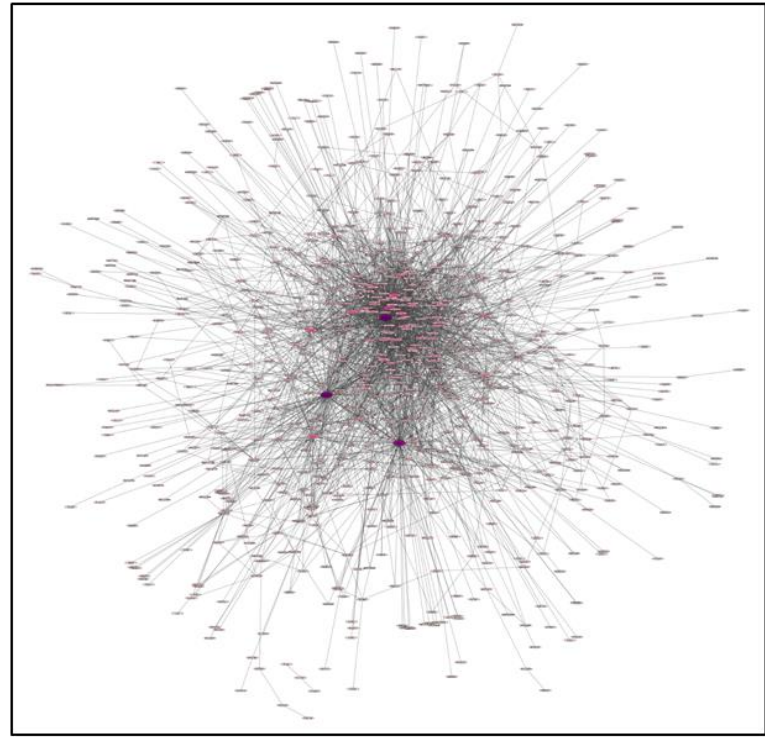

Figure 1. a) PPI network for DEGs associated with CD4+ T cells b) PPI network for DEGs associated with CD14+ monocytes c) miRNA - target gene network for GSE145191 dataset. (Nodes with higher number of interactions are darker colored and larger shaped)

The PPI network for CD14+ monocytes is denser than CD4+ T cells. The hubs for both PPI networks according to degree and betweenness metrics are shown in Table 1. There are five hubs for CD14+ monocytes (NR2C2, KRAS, APP, LARP7 and CDC5L) and six hubs for CD+4 T cells (KSR1, RAB7A, SYK, ST13, UBE2D1 and SMARCA2). There are no mutual hubs for both cell types. STI3, which is a hub for CD4+ T cells is the only mutual DEG among the hubs and it is upregulated for both cell types. 
Table 1. Hubs of the PPI network for different cell types (hubs of each cell type are shown in bold)

\begin{tabular}{cccc|cccc}
\hline \multicolumn{4}{c|}{ CD14+ Monocytes } & \multicolumn{4}{c}{ CD4+ T Cells } \\
\hline hubs & degree & hubs & betweenness & hubs & Degree & hubs & betweenness \\
\hline NR2C2 & 131.0 & APP & 112801.4 & JAK1 & 8.0 & KSR1 & 7082.4 \\
KRAS & 129.0 & KRAS & 106717.7 & RAB7A & 7.0 & RAB7A & 6338.4 \\
APP & 122.0 & NR2C2 & 808146.5 & SYK & 7.0 & KCTD12 & 6058.2 \\
LARP7 & 81.0 & LMNA & 367275.9 & KSR1 & 7.0 & SYK & 4584.0 \\
CHD4 & 66.0 & LARP7 & 354923.6 & HSPA4 & 6.0 & ST13 & 4469.3 \\
LMNA & 58.0 & FBXW7 & 238702.8 & UBE2D1 & 6.0 & UBE2D1 & 3931.7 \\
CDC5L & 58.0 & CDC5L & 216164.5 & ST13 & 6.0 & VAV2 & 3869.8 \\
NRAS & 58.0 & CALM1 & 177510.2 & VAPA & 6.0 & PSMB2 & 3694.0 \\
ITGA4 & 53.0 & YWHAZ & 173068.4 & TBL1XR1 & 5.0 & RHOU & 3075.5 \\
IFI16 & 47.0 & SYNCRIP & 161082.0 & SMARCA2 & 5.0 & SMARCA2 & 3036.9 \\
\hline
\end{tabular}

There are 2523 miRNA associated with CD14+ T cells and 2225 miRNA associated with CD4+ monocytes. There are 2207 miRNA mutual between data for CD4+ and CD14+ cells. The miRNA - target gene network for CD4+ cells has 2572 nodes and 10786 edges. For CD14+ cells the network has 3394 nodes and 32868 edges. The hubs of both miRNA-target gene networks for GSE61399 data according to degree and betweenness metrics are given in Table 2. There are seven hubs for CD14+ monocytes and five hubs for CD4+ T cells. FEM1A is a hub in the miRNA - target gene network and downregulated for both cell types.

Table 2. Hubs of the miRNA -target gene network for CD4+ and CD14+ cells (hubs are shown in bold)

\begin{tabular}{cccc|cccc}
\hline \multicolumn{4}{c|}{ CD14+ Monocytes } & \multicolumn{4}{c}{ CD4+ T Cells } \\
\hline hubs & Degree & hubs & Betweenness & hubs & Degree & hubs & Betweenness \\
\hline FEM1A & 229.0 & FEM1A & 497476.0 & UBN2 & 478.0 & UBN2 & 313508.2 \\
TNRC6B & 201.0 & CDK6 & 400795.0 & PPP1R15B & 473.0 & FEM1A & 310711.1 \\
CDK6 & 188.0 & TNRC6B & 384570.7 & DNAJB9 & 353.0 & PPP1R15B & 293468.6 \\
DCAF7 & 174.0 & DCAF7 & 315727.9 & MYLIP & 344.0 & hsa-miR-16-5p & 278630.7 \\
CYCS & 137.0 & hsa-miR-335-5p & 211859.6 & VMP1 & 337.0 & YWHAZ & 245728,4 \\
KLHDC10 & 124.0 & KMT2A & 196048.1 & FEM1A & 332.0 & LDLR & 222504.0 \\
TFDP2 & 121.0 & ACTB & 192948.4 & BZW1 & 324.0 & hsa-miR-335-5p & 219017.8 \\
ZBTB20 & 117.0 & MYLIP & 183280.8 & LDLR & 314.0 & BZW1 & 214986.2 \\
RAB32 & 117.0 & KLHDC10 & 179472.2 & BCL2L11 & 307.0 & TNRC6B & 206782.4 \\
MYLIP & 114.0 & CYCS & 176564.8 & YWHAZ & 302.0 & MED28 & 202751.4 \\
\hline
\end{tabular}

Differentially expressed miRNAs for Behcet's disease were also identified through analyzing GSE145191 dataset with samples from platelets-free plasma. The miRNA analysis yielded a differentially expressed miRNA list with 196 upregulated and 66 downregulated miRNAs totaling 262 for homo sapiens. Mutual miRNA for both datasets and three different sample types is 72 .

The construction of miRNA-Target gene interaction network for GSE145191 dataset yielded 402 nodes and 707 edges (Figure 1). There are eight hub miRNA's (hsa-miR-17-5p, hsa-miR-603, hsa-miR-375, hsamiR-107, hsa-miR-454-3p, hsa-miR-650, hsa-miR-142-3p and hsa-miR-765) mutual in the hub analysis considering both metrics (Table 3). These hub miRNAs are also in the mutual miRNA list for the GSE61399 dataset. 
Table 3. miRNA - target gene hub analysis according to the selected metrics.

\begin{tabular}{lclc}
\hline \multicolumn{1}{c}{ Hubs } & Degree & \multicolumn{1}{c}{ Hubs } & Betweenness \\
\hline hsa-miR-17-5p & 82.0 & hsa-miR-17-5p & 54067.7 \\
hsa-miR-603 & 34.0 & hsa-miR-603 & 21259.1 \\
hsa-miR-520b & 29.0 & hsa-miR-375 & 16275.8 \\
hsa-miR-375 & 29.0 & hsa-miR-107 & 14292.9 \\
hsa-miR-107 & 28.0 & hsa-miR-454-3p & 12879.9 \\
hsa-miR-454-3p & 26.0 & hsa-miR-650 & 11276.8 \\
hsa-miR-512-3p & 23.0 & hsa-miR-142-3p & 10989.1 \\
hsa-miR-142-3p & 22.0 & hsa-miR-30e-5p & 10703.1 \\
hsa-miR-650 & 21.0 & UBN2 & 10686.9 \\
hsa-miR-765 & 19.0 & hsa-miR-765 & 9924.9 \\
\hline
\end{tabular}

Enrichment analysis was done for DEGs of both cell types. Arthritis may be mutual disease association for both data. Enrichment analysis was also done to identify signaling pathways. There are three mutual signaling pathways (hsa04666: Fc gamma R-mediated phagocytosis, hsa04520: Adherens junction and hsa04145: Phagosome). The Top five diseases and signaling pathways associated with both cell types are listed in Table 4.

Table 4. Top Five Diseases and Signaling Pathways Associated with GSE61399

\begin{tabular}{|c|c|c|c|}
\hline \multicolumn{2}{|c|}{ CD4+ T Cells } & \multicolumn{2}{|l|}{ CD14+ Monocytes } \\
\hline \multicolumn{4}{|c|}{ Disease Association } \\
\hline Term & PValue & Term & PValue \\
\hline $\begin{array}{l}\text { Hepatitis, } \\
\text { autoimmune }\end{array}$ & 0.0028 & $\begin{array}{l}\text { Familial Mediterranean Fever; hyper-IgD } \\
\text { syndrome }\end{array}$ & 4,19E-04 \\
\hline Rheumatoid Arthritis & 0.0043 & $\begin{array}{l}\text { Diarrhea | Familial Mediterranean Fever I } \\
\text { Pain I Stomatitis, Aphthous }\end{array}$ & 0,0066 \\
\hline Vascular Diseases & 0.0044 & $\begin{array}{l}\text { Amyloidosis | Behcet Syndrome | } \\
\text { Familial Mediterranean Fever I Irritable } \\
\text { Bowel Syndrome }\end{array}$ & 0,0066 \\
\hline Tobacco Use Disorder & 0.0049 & $\begin{array}{l}\text { Head and Neck Neoplasms I Neoplasm } \\
\text { Recurrence, Local I Neoplasms, Second } \\
\text { Primary }\end{array}$ & 0,0066 \\
\hline Myocardial Infarction & 0.0059 & Arthritis & 0,00672 \\
\hline \multicolumn{4}{|c|}{ Signaling Pathways Association } \\
\hline Term & PValue & Term & PValue \\
\hline $\begin{array}{l}\text { hsa04380:Osteoclast } \\
\text { differentiation }\end{array}$ & 0.0014 & hsa04915:Estrogen signaling pathway & 0,0051 \\
\hline $\begin{array}{l}\text { hsa05145:Toxoplasmos } \\
\text { is }\end{array}$ & 0.0015 & hsa04010:MAPK signaling pathway & 0,0063 \\
\hline hsa05152:Tuberculosis & 0.0042 & hsa04350:TGF-beta signaling pathway & 0,0116 \\
\hline $\begin{array}{l}\text { hsa04666:Fc gamma R- } \\
\text { mediated phagocytosis }\end{array}$ & 0.0045 & $\begin{array}{l}\text { hsa04722:Neurotrophin signaling } \\
\text { pathway }\end{array}$ & 0,0222 \\
\hline $\begin{array}{l}\text { hsa05412:Arrhythmog } \\
\text { enic right ventricular } \\
\text { cardiomyopathy }\end{array}$ & 0.0059 & hsa04145:Phagosome & 0,0244 \\
\hline
\end{tabular}


Reporter metabolite analysis was also done for GSE61399 dataset for both cell types. There were 81 reporter metabolites associated with CD4+ cells and 91 reporter metabolites associated with CD14+ cells. There are only three mutual metabolites: [protein]-L-serine (C02189), guanidinoacetate (C00581) and histone-L-lysine (C02415). Metabolic pathways associated with both cell types were also uncovered. There were 3 metabolic pathways associated with CD4+ cells and 9 metabolic pathways associated with CD14+ cells. There was only one mutual metabolic pathway: O-Glycan biosynthesis. The five metabolic pathways with lowest p-values are listed in Table 5. Diseases associated with the metabolites of each cell type were also identified. While there were no mutual disease associations, several diseases came into prominence for each cell type such as Hypertension and diabetes for CD14+ Monocytes and epilepsy and schizophrenia for CD4+ T cells.

Table 5. Top Five Metabolic Pathways and Diseases associated with GSE61399

\begin{tabular}{ll|lll}
\hline \multicolumn{4}{c}{ CD14+ Monocytes } & \multicolumn{2}{c}{ CD4+ T Cells } \\
\hline Annotation & $p$-value & Annotation & p-value \\
\hline Biosynthesis of unsaturated fatty acids & $2.48 \mathrm{E}-03$ & Metabolism of xenobiotics by cytochrome P450 & $7.42 \mathrm{E}-09$ \\
GnRH signaling pathway & $3.37 \mathrm{E}-05$ & Aminoacyl-tRNA biosynthesis & $1.23 \mathrm{E}-10$ \\
Fatty acid biosynthesis & 0.0001 & ABC transporters & $4.36 \mathrm{E}-06$ \\
Fc gamma R-mediated phagocytosis & 0.0001 & Valine, leucine and isoleucine biosynthesis & 0.0032 \\
Long-term depression & 0.0002 & Cysteine and methionine metabolism & 0.0042 \\
\hline \multicolumn{2}{c}{ Disease Association } & \\
\hline Annotation & $p$-value & Annotation & -value \\
\hline Essential hypertension & $2.52 \mathrm{E}-05$ & Leukemia & $3.55 \mathrm{E}-12$ \\
Gestational diabetes & $5.01 \mathrm{E}-05$ & Epilepsy & $2.17 \mathrm{E}-07$ \\
Headache & 0.0014 & Schizophrenia & $2.10 \mathrm{E}-06$ \\
Hypertension & 0.0023 & Heart failure & 0.0002 \\
Thyroid cancer & 0.0234 & Dengue fever & 0.0005 \\
\hline
\end{tabular}

\section{DISCUSSION}

In this study differentially expressed genes and miRNA's of Behcet's Disease were explored through computational analysis. Samples of the gene expression data analyzed were taken from isolated CD4+ T cells and CD14+ monocytes of PMBC, and for miRNA expression data they were taken from platelet free plasma. Interaction networks for DEGs and differentially expressed miRNA were constructed and hubs of these interaction networks were identified. Transcriptional regulators of the disease genes were put forward. The gene expression data was enriched with signaling pathways and diseases associated with the Behcet's DEGs. Reporter metabolites and metabolic pathways linked to DEGs were also displayed.

From the 73 mutual DEGs for GSE61399 there was only one mutual Transcriptional Factor; ZEB2 (Zinc finger E-box-binding homeobox 2) and it shows different regulation direction in each cell type. ZEB2 functions as a DNA-binding transcriptional repressor and is involved in pathways that regulate early growth and development. Mutations in this gene have been associated with Hirschsprung disease/MowatWilson syndrome (Garavelli and Mainardi 2007) . Deficiency of this protein causes disruption in the formation of organs and tissues before birth. FEM1A (Fem-1 Homolog A) which is a hub for miRNA target gene network of GSE6161399 dataset has been downregulated in both cell types. It is sex gene which has been previously associated with polycystic ovary syndrome (Goodarzi et al. 2008).

Distinct number of hub proteins emerged as a result of the interaction network analysis. None of these hub proteins were TFs and there were no mutual hub proteins between the different cell types. For CD14+ Monocytes, NR2C2 and APP are the top hubs for degree and betweenness metrics respectively. NR2C2 
(Nuclear Receptor Subfamily 2 Group C Member 2) gene encodes a protein that is from the nuclear hormone receptor family. This protein functions as protector of cells from oxidative stress. Overexpression of NR2C2 has been associated with adenoma progression previously (Yao et al. 2019). NR2C2 has been downregulated in this study. APP (Amyloid Precursor Protein) functions as a cell surface receptor and is involved in cell mobility through interacting proteins. Amyloid beta peptides are a notable part of amyloid plaques found in Alzheimer's patients (O'Brien and Wong 2011). Behcet's disease has been previously linked to renal diseases such as amyloidosis which is the formation of soft tissue in kidneys and most common cause of renal failure for this disease (Akpolat et al. 2008). For CD4+ T cells, RAB7A and SYK are hub proteins among several others. RAB7A (Member RAS Oncogene Family) is from a family of proteins that regulate vesicular transport. Mutations in this gene causes Charcot-Marie-Tooth Disease which induces damage to peripheral nerves (Reilly et al. 2011). RAB7A is downregulated in Behcet's Disease. SYK (Spleen Tyrosine Kinase) which is also dysregulated in the analysis is a modulator of epithelial cell growth. SYK inhibitors are used in treatment of rheumatic diseases (Deng et al. 2016). Joint pain and swelling in knees and elbows are common symptoms for Behcet's Disease and Rheumatic diseases. ST13 (Progesterone Receptor-Associated P48 Protein) which is another hub for CD4+ T cells is mutually upregulated in both cell types.

In this study eight hub miRNAs were prominent in both datasets and three cell types. hsa-miR-17-5p regulates cell cycle to stimulate cell proliferation. Previous studies show hsa-miR-17-5p function as an oncogenic miRNA in cancer progression (Wang et al. 2019). In another study, hsa-miR-17-5p was down regulated in women with endometriosis (Jia et al. 2013). Another hub miRNA of this study, hsa-miR-375, is shown to promote inflammatory bowel disease through upregulation of TLR4 (Wu et al. 2019). Recently hsa-miR-375 has been put forward as a biomarker for migraine aura (Gallelli et al. 2019). hsa-miR-603 has been proposed as a marker for amyotrophic lateral sclerosis as well as Alzheimer's Disease previously (Zhang et al. 2016; Foggin et al. 2019). Prior studies have linked hsa-miR-765, another hub miRNA, to coronary disease, several cancers as well as Kawasaki Disease (Chen et al. 2018). The eight hub miRNAs of the study are mutual for all datasets, so it is safe to say that they can be candidate biomarkers of Behcet's disease for CD4+ and CD14+ cells and platelet free plasma.

The GSE61399 dataset has a common disease for both cell types: Arthritis. This disease is common in Behcet's Disease patients and it can show up as different forms in different patients (Park 1999). The data was also enriched for signaling pathways and three mutual signaling pathways have been put forth. Fc gamma R-mediated phagocytosis is a crucial part of the innate immune response and is important in response to infections. This pathway is commonly dysregulated in inflammatory diseases such as Behcet's and Crohn's (Mkaddem et al. 2019). Adherens junction is another mutual signaling pathway for both cell types. The disconnection between Adherens junctions and the underlying cytoskeleton may cause outflow of plasma components into the neighboring tissues, which leads to edema which is a major symptom of Behcet's Disease (Bouillet et al. 2013). The other mutual pathway for both cell types is Phagosome. Phagocytes remove unfamiliar particles, bacteria, and dead cells to protect the body. This process is called phagocytosis which is actually a defense mechanism against infectious agents. A phagosome is formed, achieves digestive properties when specific receptors on the phagocyte surface recognize ligands on the particle surface and matures through interaction with other membrane organelles. The fusion of phagosomes and lysosomes releases toxic products that kill most bacteria and degrade them into fragments. Dysregulation of phagosome pathway may result in problems with degradation of bacteria, dead cells or unfamiliar particles. Previous studies indicate a phagocytic dysfunction in severe Behcet's disease cases (Perazzio et al. 2015).

In this study there are three mutual metabolites: [protein]-L-serine (C02189), guanidinoacetate (C00581) and histone-L-lysine (C02415) that come forward as a result of the analysis. A recent study has identified various metabolites associated with Behcet's disease using synovial fluids (Ahn et al. 2015). This study has a comprehensive list of metabolites which includes L-serine but does not include guanidinoacetate and histone-L-lysine. Guanidinoacetate is used as a biomarker to differentiate between Arginine glycine amidinotransferase deficiency and Guanidinoacetate methyltransferase deficiency. It 
should be further looked into as a biomarker of Behcet's Disease. There was only one mutual metabolic pathway in the analysis: O-Glycan biosynthesis. O-linked glycans function in cellular activities such as protein stability, immunity, receptor-mediated signaling and protein expression. They also mediate recognition between proteins. Dysregulation of this metabolic pathway in known to cause congenital disorders in humans (Wopereis et al. 2006) as well as infectious diseases (Taylor et al. 2018).

In conclusion this study pinpoints several hub proteins, hub miRNA, signaling pathways and diseases associated with Behcet's Disease as well as reporter metabolites and metabolic pathways through a systems biology approach. This study also exhibits the diversity of the analysis results according to sample types. Due to the lack of additional Microarray datasets for Behcet's disease, two different cell types were analyzed. This may be regarded as a limitation of this study. Though there are mutual DEGs there were no mutual hub proteins for both cell types. The hub miRNA and reporter metabolites could be evaluated further in experimental studies for their biomarker capacities. Moreover, these biomarker candidates may be helpful in the design of a diagnostic kit for the disease.

\section{REFERENCES}

Agren R, Liu L, Shoaie S, et al (2013) The RAVEN Toolbox and Its Use for Generating a Genome-scale Metabolic Model for Penicillium chrysogenum. PLoS Comput Biol. https://doi.org/10.1371/journal.pcbi.1002980

Ahn JK, Kim S, Kim J, et al (2015) A comparative metabolomic evaluation of behcet's disease with arthritis and seronegative arthritis using synovial fluid. PLoS One. https://doi.org/10.1371/journal.pone.0135856

Akpolat T, Dilek M, Aksu K, et al (2008) Renal Behçet's Disease: An Update. Semin Arthritis Rheum. https://doi.org/10.1016/j.semarthrit.2007.11.001

Barrett T, Wilhite SE, Ledoux P, et al (2013) NCBI GEO: Archive for functional genomics data sets Update. Nucleic Acids Res. https://doi.org/10.1093/nar/gks1193

Benjamini Y, Hochberg Y (1995) Controlling the False Discovery Rate: A Practical and Powerful Approach to Multiple Testing. J R Stat Soc Ser B. https://doi.org/10.1111/j.25176161.1995.tb02031.x

Bertolazzi P, Bock ME, Guerra C (2013) On the functional and structural characterization of hubs in protein-protein interaction networks. Biotechnol. Adv.

Bouillet L, Baudet AE, Deroux A, et al (2013) Auto-antibodies to vascular endothelial cadherin in humans: Association with autoimmune diseases. Lab Investig. https://doi.org/10.1038/labinvest.2013.106

Bovolenta LA, Acencio ML, Lemke N (2012) HTRIdb: an open-access database for experimentally verified human transcriptional regulation interactions. BMC Genomics. https://doi.org/10.1186/1471-2164-13-405

Chatr-Aryamontri A, Oughtred R, Boucher L, et al (2017) The BioGRID interaction database: 2017 update. Nucleic Acids Res. https://doi.org/10.1093/nar/gkw1102

Chen Y, Ding YY, Ren Y, et al (2018) Identification of differentially expressed MicroRNAs in acute Kawasaki disease. Mol Med Rep. https://doi.org/10.3892/mmr.2017.8016

Chin $\mathrm{CH}$, Chen SH, Wu HH, et al (2014) cytoHubba: Identifying hub objects and sub-networks from complex interactome. BMC Syst Biol. https://doi.org/10.1186/1752-0509-8-S4-S11

Chou CH, Shrestha S, Yang CD, et al (2018) MiRTarBase update 2018: A resource for experimentally validated microRNA-target interactions. Nucleic Acids Res. https://doi.org/10.1093/nar/gkx1067

Deng GM, Kyttaris VC, Tsokos GC (2016) Targeting syk in autoimmune rheumatic diseases. Front. Immunol.

Excoffier L, Gouy A, Daub JT, et al (2017) Cytoscape: A Software Environment for Integrated Models of Biomolecular Interaction Networks. Nucleic Acids Res. https:/doi.org/10.1093/nar/gkx626

Foggin S, Mesquita-Ribeiro R, Dajas-Bailador F, Layfield R (2019) Biological significance of microRNA 
biomarkers in ALS-innocent bystanders or disease culprits? Front. Neurol.

Gallelli L, Cione E, Peltrone F, et al (2019) Hsa-miR-34a-5p and hsa-miR-375 as Biomarkers for Monitoring the Effects of Drug Treatment for Migraine Pain in Children and Adolescents: A Pilot Study. J Clin Med. https://doi.org/10.3390/jcm8070928

Garavelli L, Mainardi PC (2007) Mowat-Wilson syndrome. Orphanet J Rare Dis. https://doi.org/10.1186/1750-1172-2-42

Goodarzi MO, Maher JF, Cui J, et al (2008) FEM1A and FEM1B: Novel candidate genes for polycystic ovary syndrome. Hum Reprod. https://doi.org/10.1093/humrep/den324

Huang DW, Sherman BT, Lempicki RA (2009) Systematic and integrative analysis of large gene lists using DAVID bioinformatics resources. Nat Protoc. https://doi.org/10.1038/nprot.2008.211

Jia SZ, Yang Y, Lang J, et al (2013) Plasma miR-17-5p, miR-20a and miR-22 are down-regulated in women with endometriosis. Hum Reprod. https://doi.org/10.1093/humrep/des413

Kanehisa M, Furumichi M, Tanabe M, et al (2017) KEGG: New perspectives on genomes, pathways, diseases and drugs. Nucleic Acids Res. https://doi.org/10.1093/nar/gkw1092

López-Ibáñez J, Pazos F, Chagoyen M (2016) MBROLE 2.0-functional enrichment of chemical compounds. Nucleic Acids Res. https://doi.org/10.1093/nar/gkw253

Mardinoglu A, Agren R, Kampf C, et al (2014) Genome-scale metabolic modelling of hepatocytes reveals serine deficiency in patients with non-alcoholic fatty liver disease. Nat Commun. https://doi.org/10.1038/ncomms4083

Mkaddem S Ben, Benhamou M, Monteiro RC (2019) Understanding Fc receptor involvement in inflammatory diseases: From mechanisms to new therapeutic tools. Front. Immunol.

Mudunuri U, Che A, Yi M, Stephens RM (2009) bioDBnet: The biological database network. Bioinformatics. https://doi.org/10.1093/bioinformatics/btn654

O'Brien RJ, Wong PC (2011) Amyloid precursor protein processing and alzheimer's disease. Annu Rev Neurosci. https://doi.org/10.1146/annurev-neuro-061010-113613

Park JH (1999) Clinical analysis of Behçet disease: arthritic manifestations in Behçet disease may present as seronegative rheumatoid arthritis or palindromic rheumatism. Korean J Intern Med. https://doi.org/10.3904/kjim.1999.14.1.66

Perazzio SF, Soeiro-Pereira P V., de Souza AWS, et al (2015) Behçet's disease heterogeneity: Cytokine production and oxidative burst of phagocytes are altered in patients with severe manifestations. Clin Exp Rheumatol

Puccetti A, Fiore PF, Pelosi A, et al (2018a) Gene expression profiling in behcet's disease indicates an autoimmune component in the pathogenesis of the disease and opens new avenues for targeted therapy. J Immunol Res. https://doi.org/10.1155/2018/4246965

Puccetti A, Pelosi A, Fiore PF, et al (2018b) MicroRNA expression profiling in behçet's disease. J Immunol Res. https://doi.org/10.1155/2018/2405150

Reilly MM, Murphy SM, Laurá M (2011) Charcot-Marie-Tooth disease. In: Journal of the Peripheral Nervous System

Segundo-Val IS, Sanz-Lozano CS (2016) Introduction to the gene expression analysis. In: Methods in Molecular Biology

Sevimoglu T, Arga KY (2014) The role of protein interaction networks in systems biomedicine. Comput Struct Biotechnol J 11:22-27. https://doi.org/10.1016/J.CSBJ.2014.08.008

Smyth GK, Ritchie M, Thorne N (2011) Linear Models for Microarray Data User ' s Guide. Bioinformatics. https://doi.org/10.1093/nar/gkv007

Taylor SL, McGuckin MA, Wesselingh S, Rogers GB (2018) Infection's Sweet Tooth: How Glycans Mediate Infection and Disease Susceptibility. Trends Microbiol.

Tong B, Liu X, Xiao J, Su G (2019) Immunopathogenesis of Behcet's disease. Front. Immunol.

van der Houwen T, van Laar J (2020) Behçet's disease, and the role of TNF- $\alpha$ and TNF- $\alpha$ blockers. Int. J. Mol. Sci.

Wang W, Dong R, Guo Y, et al (2019) CircMTO1 inhibits liver fibrosis via regulation of miR-17-5p and 
Smad7. J Cell Mol Med. https://doi.org/10.1111/jcmm.14432

Wopereis S, Lefeber DJ, Morava É, Wevers RA (2006) Mechanisms in protein O-glycan biosynthesis and clinical and molecular aspects of protein O-glycan biosynthesis defects: A review. Clin. Chem.

Wu CP, Bi YJ, Liu DM, Wang LY (2019) Hsa-miR-375 promotes the progression of inflammatory bowel disease by upregulating TLR4. Eur Rev Med Pharmacol Sci.

https://doi.org/10.26355/eurrev_201909_18871

Yao X, Zhang Y, Wu L, et al (2019) Immunohistochemical Study of NR2C2, BTG2, TBX19, and CDK2 Expression in 31 Paired Primary/Recurrent Nonfunctioning Pituitary Adenomas. Int J Endocrinol. https://doi.org/10.1155/2019/5731639

Zhang C, Lu J, Liu B, et al (2016) Primate-specific miR-603 is implicated in the risk and pathogenesis of Alzheimer's disease. Aging (Albany NY). https://doi.org/10.18632/aging.100887 